\title{
Critical Reflection as Motivational Strategy of Learning Critical Reading
}

\author{
Yeshambel Tadele Alem \\ TEFL Program, Bahir Dar University, Ethiopia
}

\begin{abstract}
The study investigated the effect critical reflection exerted on students' motivation of learning EFL critical reading. In this respect, the present study conducted quasi-experimental research design. 32 participants were involved in the control group while 31 were in the experimental one. According to the preintervention questionnaire results by using independent samples T-test test of data analysis, participants of the control and the experimental groups were almost homogeneously motivated while learning critical reading although random assignment was not possible. In similar with the pre-intervention questionnaire, 30 questions were also asked to participants (control and experimental groups) as post-intervention questionnaire to evaluate to what extent participants improved their motivation of learning EFL critical reading after practicing critical reflection. The post-intervention questionnaire results proved that critical reflection has the effect in enhancing students' motivation of learning EFL critical reading regarding independent samples Ttest test of data analysis.
\end{abstract}

Index Terms_critical reflection, learning critical reading, motivational strategy

\section{INTRODUCTION}

In the twenty-first century, education needs to keep pace for the rapid changes of the world and for educational settings in a variety of socio-cultural, political and economic aspects. In this respect, teaching and learning at different levels of education needs to provide opportunity to students to be engaged in a complex and dynamic world deeply (EUCIS-LLL, 2012; Bolstad and Gilbert, 2012; Freire, 1974 and 1985). To be responsive for a complex and dynamic world, educators have planned to have open design for critical, collaborative and team teaching and learning that matches with the social and cultural aspects of EFL classes (Bolstad and Gilbert, 2012). To this fact, students and teachers need to be involved on critical reflection in and/or outside teaching and learning classes (Bolstad and Gilbert, 2012) because it responds for a situation of fluidity, unpredictability and complexity (Bolstad and Gilbert, 2012).

Similarly, teaching and learning critical reading needs situational and flexible strategy that can answer multidimensional questions of students, teachers and overall society in the context of the study. The situation of EFL teaching and learning is not static by its nature, particularly at teaching and learning critical reading. Therefore, in reading classes, students from different contexts do not need similar or water-flow like teaching and learning classes because they come to school from different social, cultural, political and economic dimensions. To address those students, students and teachers need to reflect their reading classes' experiences critically while and/or after critical reading teaching and learning proceeds. If practicing critical reflection provides opportunity to students to analyze, to reconsider and to question what is going on in classes, their motivation may be enhanced to learn critical reading in an effective way

\section{A. Critical Reflection}

Different educators have provided their views on the concept of critical reflection in their own perspectives although the common sense of it stated by them is similar. Schön (1983), Redmond (2004) and Dewey (1933) defined critical reflection as it is the term "critical" broadens the perspectives of reflection by bringing into focus the socio-cultural context and historical events of classes. Freire $(1972,1974)$ also states that instead of the term reflection, critical reflection is thought to deal socio-cultural factors and subjectivities teachers and students face in classes. Moreover, in view of Richards (1990), the terms 'reflection' and 'critical reflection' can be used interchangeably in teaching and learning classes. In addition, Bartlett (1990), Calderhead (1989), Jay and Johnson (2002) in Al-Kalbani (2007) revealed that critical reflection can be defined into five directives: reflective teaching from a technical perspective, a contextual perspective, an experiential or a deliberative perspective and a critical perspective. Brookfield (1990) also states that critical reflection is a way of analysis on teaching and learning strategies, methods, or overall aspects of teaching and learning experiences including social and cultural aspects of teaching and learning classes.

The concept of critical reflection has ancient origins (Nussbaum, 1997 in Fook and Gardner, 2007). The origin of critical reflection goes back to the philosophy of Socrates (Bartlett, 1990). "Socrates, for example, stressed the centrality of critical self-examination, or living the 'examined life', for ethical, compassionate, humane engagement with the world and its moral dilemmas" (Nussbaum, 1997 in Fook and Gardner, 2007, p. 8). 
Educators, then after, often acknowledge the US educationalist, Dewey as the originator of the modern concept of reflection although he took the ideas of classic educators, such as Aristotle, Plato, and Confucius (Gibbs, 1988; Rolfe et al., 2001; Driscoll, 2007; John, 2009). Mezirow (1990) and Redmond (2004) also suggested that the original and innovative assumption of Dewey $(1916,1933)$ has a cornerstone value to the development of the current notions of reflection. Meaning, practical insight of reflective practice for teaching and learning was originated from the views of US educationalist Dewey in 1910, 1916 and 1933 (Bartlett, 1999; Samuel, 1999; Carter et al., 2013). In relation to this, Carter et al. (2013) states Dewey, considered the father of modern education, "wrote about reflective teaching over a century ago" (P. 16). In view of Carter et al. (2013), then after, reflective practice has been supported by Kolb and Fry (1975), Schön (1983, 1987), Gibbs (1988), Rolfe et al. (2001), Driscoll (2007) and John (2009) in their own aspects of learning theories.

In a particular context, a single theory of learning is not possible to make the process of learning challenge free because different aspects of learning need responses from different theories of learning (Mezirow, 2000, Brookfield, 1995; Carter et al., 2013). A variety of models, sets of assumptions and principles, theories, and explanations in a single context of learning can be viewed as bases of knowledge and skills (Knowles, 1980; Cross, 1981; Freire, 2000 in Mezirow, 2000). To this end, teachers and students need to be familiar on these integrated learning theories those can be viewed in a single context of learning (Mezirow, 2000, Brookfield, 1995; Carter et al., 2013) because the more educators are familiar with these theories, the more effective their practice can be, and the more responsive their practice can be to the needs of students (Freire, 2000). Therefore, in most cases, three major theories: andragogy, selfdirected learning and transformational learning together with their practices are expected in the twenty first- century teaching and learning classes (Knowles, 1980; Cross, 1981; Mezirow, 2000).

In a similar vein, critical reflection has different theoretical backgrounds: constructivism, socio-cultural theory, experiential learning, critical theories and postmodern thought (Driscoll, 2007; Fook, 2010; Kolb and Fry, 1975; Schön, 1983; Freire, 1974, 1992; Brookfield, 1995; Mezirow, 2006). These theories in one and the other way grouped under three major theories: andragogy (the art and science of helping students learn but not the art and science of teaching students) (Knowles, 1980), self-directed learning (Cross, 1981), and transformational learning (Freire, 2000 in Mezirow, 2000). Having had a common sense about reflective practice and critical reflection, theorists theorized different models and frameworks which are applicable and practicable to run teaching and learning in a progressive manner: transformational learning (Mezirow, 2006), consciousness-raising and critical pedagogy (Freire, 1974), experiential learning (Kolb, 1984) and the learning organization (Schön, 1983).

Critical reflection in the thought of constructivists' theory allows students to construct their own understanding and knowledge of the world through experiencing things and reflecting on these experiences (Lowenthal and Muth, 2008). The process of EFL teaching and learning is also grounded in the socio-cultural theory of Vygotsky; this provides a room for meaningful interaction one another among teachers and students to critically reflect on difficulties or best practices of teaching and learning classes (Murphy, 2009; Lantolf, 2000). And, experiential learning facilitates language learning in the process of transforming experience through critical reflection in view of the learning cycle of Kolb (1984) originated from Dewey, Piaget, and Lewin's views of integrated philosophy of reflection, interdependent/interactive psychological perspectives, and individual inner mental processing respectively display a special insight in facilitating teaching and learning (Ghaye, 2001; Walker et al., 2013).

Brookfield (1995), Freire (1992) and Mezirow (2006) argue that critical theory contributes to have deep reflection to promote teaching and learning processes a step forward. In the thought of critical pedagogy, students and teachers are considered as facilitators of changes through their active participation about the world to view their education as a practice of freedom (Brookfield, 1995; Freire, 1992). In view of critical theory of learning, students are not the founders of wisdom in the process of received knowledge; rather education is an active process in which the learners actively involved through critical reflection for the sake of determining logical and reasonable rationales (Brookfield, 1995; Freire, 1992). Students and teachers have a tendency to reject any ideas that do not correspond to their particular values, associations and concepts. In a total sense, critical reflection, stemming from critical social theory, has played a role in emancipator and transformational practice development (Brookfield, 1995; Freire, 1992).

Kumaravadivelu (2001) also stated that critical reflection is the perspective of postmodern deconstructive teaching and learning assumption. Postmodern thought permits students and teachers to critically reflect on the experience of teaching and learning to obtain convenient strategies as well as new unpredictable assumptions for immediate classes (Kumaravadivelu, 2001). In this sense, critical reflection in view of postmodern thought permits to have socio-cultural analyses which enable transformative change for the immediate teaching and learning classes (White et al., 2006).

\section{B. Critical Reflection as Motivational Strategy of Learning Critical Reading}

EFL Teaching and learning is challenging in a foreign language setting, where authentic language input is not readily accessible outside classes and it is subject to a number of external and internal issues in the societies where critical reflection is the best option to reduce the challenge (Gardner, 1985, 2006; Gardner and Lambert, 1972). If a number of external and internal issues of EFL reading classes are critically reflected, students' critical reading learning motivation can be enhanced because critical reflection can handle positive attitudes of students to learn (Wheeler, 2007; Dornyei, 2001). To this end, educators and educational psychologists like Gardner and his colleagues have searched how students can be motivated to their learning through consistent practice of critical reflection. 
Gardner and Lambert (1972), Gardner (1985, 2006), Brookfield (1995), Freire (1972), Mezirow (2006) and Larrivee (2000) viewed that motivation for learning can be enhanced if students' social, cultural, political, economic questions are responded. Students in classes may not be motivated only through responding technical and practical challenges of EFL classes; rather students' socio-affective natures need to be analyzed critically (Gardner, 2006; Brookfield, 1995; Freire, 1972). To analyze socio-affective natures of teaching and learning classes, teachers and students need to practice critical reflection as a strategy (Freire, 1972; Brookfield, 1995; Mezirow, 2006; Larrivee, 2000) because critical reflection helps to analyze students' and teachers' beliefs and attitudes including socio-cultural components in order to motivate students to their learning. In relation to this, Gardner and Lambert (1972) revealed that EFL students need to have a knowhow towards the linguistic-cultural community of the target language to create positive attitude among EFL students to have an influence on the success of English as foreign language learning with a high motivation.

In view of Gardner (1985, 2006), Dornyei (2001) and Brown (2001), motivation is a combination of different issues in teaching and learning classes: students' desire, positive attitude, critical judgment of students about learning, the way the teacher teaches, and the way learning activities presented. To analyze students' desire and positive attitude and other learning motivation issues, critical reflection needs to be practiced before and/or after classes (Locke and Latham, 1990; Deci et al., 1999; Ryan and Deci, 2000). EFL teachers' and students' involvement on critical reflection leads to choose appropriate contents in relation with the socio-cultural aspects of teaching and learning classes that can enhance students' motivation to learn (Dornyei, 2001; Brown, 2001; Gardner, 1985, 2006). Although basic principles of learning, motivation, and effective instruction are applied to all students, students have different performances, capabilities, and preferences of learning and strategies (Brown, 2001; Ryan and Deci, 2000). Brown (2001) emphasizes that these diversified students' learning motivation can be encouraged through critical reflection because critical reflection as an aspect of meta-cognitive and students' motivation has significant correlation (Martin, 2008; Linnenbrink and Pintrich, 2002; Mezirow, 2006; Larrivee, 2000).

However, Icemez (2005), Granville (2003), AbdKadir et al. (2014), Al-Oqaili (2007) and El-Maleh (2006) state that many EFL teachers and students have not practiced critical reflection in teaching and learning critical reading effectively due to minimum extent of students' motivation. Inappropriate uses of strategies for motivation leads students to minimum arousal to learn critical reading, unable to link their own realities and reading lessons and unable to control their learning (Icemez, 2005; Granville, 2003); to this end, students have poor ability to use the critical reading skills satisfactorily. Likewise, EFL teachers and students at secondary schools have numerous constraints that limit practicing effective teaching and learning (Midraj et al., 2008). In a specific manner, teaching and learning critical reading in reading classes is not also a challenge free process. To overcome the observed gaps of teaching and learning critical reading in EFL reading classes, academic, social, emotional interests of students need to be into considered by using critical reflection (Midraj et al., 2008).

To this fact, the current study is proposed to reveal the effect critical reflection exerts on students' motivation of critical reading that can make the study original. Therefore, the project is eager to provide awareness for unfamiliar EFL teachers and students about the effect of critical reflection as motivational strategy of learning critical reading through a research question stated below:

1. Does the use of critical reflection exert any effect on students' motivation of learning critical reading?

\section{LITERATURE REVIEW}

\section{A. What is Learning Motivation?}

Motivation is defined as "students' energy and drive to engage, learn, work effectively, and achieve to their potential at school and the behaviors that follow from this energy and drive" (Martin, 2008, p. 239). Thorkildsen (2002) also referred that motivation is important motive that activates, guides, and maintains behavior through the process. Motivation is an important condition for students who are potentially weak to upgrade their learning achievement. Pinder (1998) also defined motivation:

a set of energetic forces that originates both within as well as beyond an individual's being, to initiate work-related behavior, and to determine its form, direction, intensity and duration. Motivation is thusly manifested by attention, effort, and persistence (P. 11).

In view of Gardner (2006), defining the term motivation is challenging because "the term motivation has been viewed differently by different schools of thought" (P. 142), but Gardner (1985, p. 10) defined motivation as "the combination of effort plus desire to achieve the goal of learning the language plus favorable attitudes toward learning the language". Gardner (2006) also argues that motivation involves answering the question "why does an organism behave as it does?' Brown (2000, p. 152) defined on motivation for learning that "motivation is commonly thought of as an inner drive, impulse, emotion, or desire that moves one to a particular action". Pintrich and Schunk (2002); Dornyei (1998) provided their view on motivation that it is the way to be used for the success of language learning.

\section{B. Theories of Motivation}

In view of behaviorists, motivation is used as a reward and punishment as the way of enhancing learning. Behaviorists' theory of motivation encourages extrinsic motivation type (Deci et al., 1999). However, in the assumption of cognitivists, the term motivation linked with learner's decisions as Keller (1983, p.389) in Glasersfeld (1989) stated 
"the choices people make as to what experiences or goals they will approach or avoid, and the degree of effort they exert in that respect". Social cognitive theory emphasizes on three interactive motivational considerations: "cognitive/emotional factors, like beliefs of capabilities, environmental factors, and behavior or performance" of students (Alderman, 1999, p. 16 in Benson, 1991). Cognitive theory of learning overviews motivation as it is internal in its nature. Meaning, cognitivists stated that students can be motivated intrinsically being this theory focuses on mental processes of learning rather than social aspects.

On the other hand, constructivists argue that motivation is placed under emphasis on social contexts including individual's decisions (Alderman, 1999 in Benson, 1991; Glasersfeld, 1989). Social interaction may enhance motivation and prolong engagement with the task. Meaning, extrinsic and intrinsic motivation types can activate students' learning under constructivists' view. The way how students can be motivated by the three paradigms of teaching and learning is somewhat different, but the three thoughts of school have a common concept on motivation that motivation reveals the desires of students in learning. Motivation emphasizes for the fulfillment of needs is rewarding, requires choices and be interpreted in a social context (Deci et al., 1999).

\section{Constructivists' Theory of Motivation and Strategic Critical Reading Learning}

There are many motivation theories in preceding EFL teaching and learning in a good manner. Among these theories, Gardner (1985) established an influential motivation theory. Gardner (1985, p. 10) recommends that "motivation to acquire a foreign language is a mixture of factors including effort, desire and a positive attitude toward the language under consideration". In the assumption of Gardner (1985), these different factors of motivation at foreign language learning can be viewed differently in different paradigms of learning theories.

In the concern of constructivism view, sustaining motivation to learn is dependent on the students' confidence in their potential of learning (Glasersfeld, 1989). The experience of mastery of solving problems through critical reflection leads students to be confident on what they did. The feeling of confidence among students can make them motivated in their independent learning (Glasersfeld, 1989). Similarly, in view of constructivists, critical reflection can encourage students to be motivated to their critical reading learning in reading classes. Students critically reflect their views on the experience of teaching and learning classes to solve challenges they face and to sustain best practices (Glasersfeld, 1989). To sum up, constructivists thought that students' enthusiasm in completing challenging tasks leads them to be confident and motivated in embarking more complex challenges (Vygotsky, 1978).

\section{How Is Critical Reflection Actually Practiced as Motivational Strategy of Learning Critical Reading?}

Different strategies can be used to practice critical reflection in EFL reading classes Leijen et al (2011). Critical reflection goes to the level of informal discussions to highly structured type of analysis through writing and conversation (Leijen et al., 2011; Zalipour, 2015). Students and teachers critically reflect what they feel on the experiences EFL reading classes individually or in pair or in group (Zalipour, 2015; Osterman and Kottkamp, 1993) because of their diversified nature (Reflective Practice CD ROM, 2007). Osterman and Kottkamp (1993) magnified that the learning "begins with a problem, unexpected event or a troublesome experience" (P. 20).

As a strategy of critical reflection, different activities can be performed (Brookfield, 1988): assumption analysis, contextual awareness, imaginative speculation and reflective skepticism. Critical reflection in the step of assumption analysis, critical practitioners think about the challenges their beliefs, values, cultural practices, and social structures in order to assess their impact on their day to day happenings, while in the step of contextual awareness, critical practitioners realize their assumptions are socially and personally created in a specific historical and cultural context (Brookfield 1988; Reflective Practice CD ROM, 2007). At critical reflection in the steps of imaginative speculation and reflective skepticism, critical practitioners imagine alternative ways of thinking about phenomena in order to provide an opportunity to challenge their prevailing ways of knowing and acting and raise questions of universal truth claims or unexamined patterns of interaction through the prior three activities as a strategy of critical reflection (Brookfield, 1988; Zalipour, 2015).

In view of Surbeck et al. (1991), critical reflection can also be practiced by considering three different levels: reacting, elaborating, and contemplating. At critical reflection, in the level of reacting, critical practitioners commenting on feelings towards the learning experience, such as reacting with a personal concern about an event and in the level of elaborating, students and teachers compare reactions with other experiences, such as referring to a general principle, a theory, or a moral or philosophical position in needing further improvement (Surbeck et al., 1991). In the level of contemplating, students and teachers critically reflect on how to construct personal insights or on problems or difficulties, such as focusing on education issues, training methods, future goals, attitudes, ethical matters, or moral concerns in creating convenient teaching and learning classes (Surbeck et al., 1991). The nature of the reaction initially provided by teachers and students as well as the feedback they give or/and receive after the initial reflection can determine the extent to which they reach the contemplation level of reflection (Surbeck et al., 1991). EFL teachers and students in reading classes can be engaged in critical reflection though the following strategies: goal setting for identified weaknesses or strengths, reflective journaling, writing reflections for implemented or observed lessons, creating a growth portfolio, coaching and conferencing after teaching a lesson, and writing a reflective summary for the whole course's experiences as it is stated by Ryan and Cooper (2006). 


\section{METHOD}

Quasi-experimental research design was employed in the present research project. Pre- and post-intervention questionnaires were conducted to confirm the difference of the effect critical reflection exerted on students' motivation of learning EFL critical reading among participants in the experimental and control groups. In the present research project, quantitative data analysis method was employed to check motivation variations of pre- and post-intervention questionnaires among students in the experimental and in the control groups because of critical reflection while learning critical reading.

\section{A. Participants}

Sixty three English major $1^{\text {st }}$ year students at Finote Selam Teachers' Education College were participants of the study because critical reading to those students was assumed to be challenging and de-motivating. Out of sixty three participants, thirty were female students while the other thirty three were males. These participants were attending reading course in two groups: thirty one in group one and thirty two were in group two. The researcher assigned group one as experimental group while group two was as control group as they were in their naturally organized sections.

\section{B. Instruments}

To examine whether or to what degree the effect critical reflection exerted on students' motivation of learning EFL critical reading, standardized pre- and post-intervention questionnaires were conducted. Questionnaires helped to simplify and quantify participants' behaviors and attitudes in relation with their motivation to learn critical reading effectively (Leedy and Ormrod, 2001). Therefore, to measure the level of intrinsic and extrinsic motivation of participants before and after experimental intervention in reading classes for critical reading, the researcher used standardized questionnaires devised by Vallerand et al. (1992): cognitive consequences (concentration while learning critical reading), affective consequences (psychological wellbeing in reading classes) and behavioral consequences (behavioral intentions of learning critical reading) as sub-scales.

Vallerand's et al. (1992) subscales of motivation contains 15 items, focusing on intrinsic motivation, were provided to participants in the experimental and the comparison groups, while 15 items on extrinsic motivation were for participants in both groups before and after intervention. In other words, the questionnaires contained 30 items before and 30 items after intervention on a five point Likert Scale, consisting of five options strongly disagree, disagree, no opinion, agree, and strongly agree.

\section{Procedures}

In the present quasi-experimental research design, the following steps were performed sequentially: administration pre-intervention questionnaire to students in the control and experimental groups, practicing critical reflection as motivational strategy of learning critical reading in the experimental group, administration of post-intervention questionnaires to participants in both groups to confirm the effect critical reflection exerted on students' motivation of learning critical reading. On the side of the teacher, audio-recordings were used to make critical reflection easy to enhance students' motivation of learning critical reading. On the bases of what was recorded, practitioner teacher could critically reflect on the previous happenings teaching critical reading. After listening repeatedly what was recorded by taking some time, the practitioner teacher could critically reflect on what was taken as best practices to go ahead and filled gaps for further improvement of students' motivation of learning critical reading. During and after class, ten to fifteen minutes was provided to students to forward their feelings about the pervious teaching and learning situations of critical reading individually or in groups via interviews, formal or informal conversations, and questionnaires.

Forty eight sessions were permitted to provide a reading course to first year English major students. Out of forty eight sessions of the course, twenty five was adjusted to manipulate the treatment to participants in the experimental group but not for the controlled ones. The treatment was focused on scaffolding students' motivation of learning critical reading via critical reflection. The treatment was performed by the teacher and the students at experimental group.

To create awareness about critical reflection and how to practice critical reflection in reading classes for critical reading, practitioner teacher and students of the experimental group were provided training. Practitioners used different techniques for critical reflection: diaries, informal and formal conversations, interviews, and questionnaires. By using the aforementioned techniques of critical reflection, the practitioner teacher and the students at experimental group endeavored to enhance students' motivation of learning critical reading. In each experimental session of teaching reading for critical reading, new learning assumptions found from critical reflection were used to enhance students' motivation of learning EFL critical reading skills. The gaps assumed by the practitioner teacher via critical reflection and feedback given by students in the experimental group through conversations, interviews, and questionnaires were the focus of the next reading classes to enhance students' motivation of learning critical reading skills.

Experimental treatment, practicing critical reflection, was manipulated in the first semester between October and December 2017 at Finoteselam Teachers' Education College on the course of reading. Every session treatment was evaluated each day to overcome gaps observed and to provide attention for best practices to continue further. During the intervention, extraneous variables were provided serious attention. Except the identified issue of treatment, in all cases, students in the experimental and control group were similarly treated. Even, the teacher for two groups was similar to reduce the impact of teacher variation. And, the course modules, the time given for the sessions, course 
contents of the curriculum were the same for students in both groups. However, the researched treatment given for students in the experimental group was different from the controlled one.

However, the degree of controlling extraneous variables in the present study was not this much sensitive like experimental research design because the study was quasi-experimental research design. Participants were simply taken as they were in a natural setting without mixing via random sampling method. Without any parameter, group one was taken as experimental group while group two was for control group by assuming the two groups students can have similar extent of motivation of learning critical reading because all participants are first year English major students.

\section{RESULTS}

To analyze the results of the present quasi-experimental research, independent samples T-tests were used as tests of data analysis. The results of the pretest and posttest were analyzed on the bases of independent samples (students from the control and the experimental groups).

\section{A. Pre-intervention Questionnaire Results}

To confirm whether or not the results of pre-intervention questionnaire significantly different, the pre-intervention questionnaire results of the two group's samples were analyzed below:

TABLE I.

DESCRIPTIVE STATISTICS FOR PRE-INTERVENTION QUESTIONNAIRE

\begin{tabular}{|c|c|c|c|c|}
\hline Groups & $\mathrm{N}$ & Mean & Std. Deviation & Std. Error Mean \\
\hline Experimental & 32 & 12.62 & 1.581 & .280 \\
\hline Control & 31 & 12.68 & 1.739 & .312 \\
\hline
\end{tabular}

TABLE II.

INDEPENDENT SAMPLES T-TEST (PRE-INTERVENTION QUESTIONNAIRE)

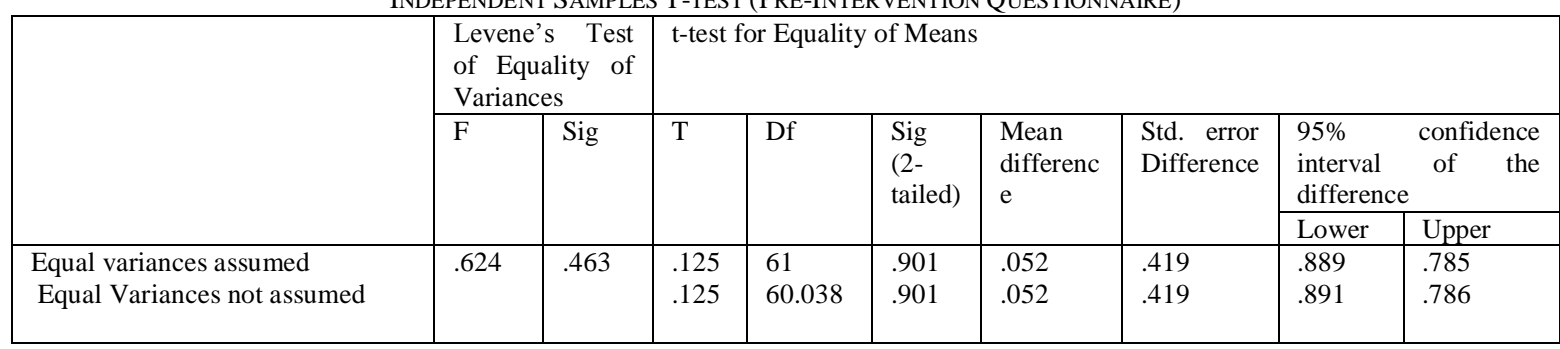

The pre-intervention questionnaire mean and standard deviations for the experimental and control groups were 12.62, 1.581 and 12.68, 1.739 respectively. According to the results analyzed from independent samples T-test, there was no significant difference between the two groups regarding their motivation of learning critical reading before the treatment was manipulated $(\mathrm{t}=0.125, \mathrm{p}=0.463)$.

\section{B. Post-intervention Questionnaire Results}

To search the effect critical reflection exerts on students' motivation of learning critical reading, post-intervention questionnaire was employed to participants of experimental and control groups. Before comparing the post-intervention questionnaire results of students in the control and experimental groups, the researcher need to analyze descriptive statistics.

TABLE III.

DESCRIPTIVE STATISTICS FOR POST-INTERVENTION QUESTIONNAIRE

\begin{tabular}{|c|c|c|c|c|c|}
\hline & $\mathrm{N}$ & Minimum & Maximum & Mean & Std. Deviation \\
\hline Experimental Group & 63 & 1 & 2 & 1.48 & .404 \\
\hline Control Group & 63 & 11 & 32 & 16.67 & 5.682 \\
\hline Valid N (listwise) & 63 & & & & \\
\hline
\end{tabular}

TABLE IV

INDEPENDENT SAMPLES TEST (POST-INTERVENTION QUESTIONNAIRE)

\begin{tabular}{|c|c|c|c|c|c|c|c|c|c|}
\hline & \multicolumn{2}{|c|}{$\begin{array}{l}\text { Levene'sTest } \\
\text { for Equality of } \\
\text { Variances }\end{array}$} & \multicolumn{7}{|c|}{ t-test for Equality of Means } \\
\hline & \multirow[t]{2}{*}{$\mathrm{F}$} & \multirow[t]{2}{*}{ Sig } & \multirow[t]{2}{*}{$\mathrm{T}$} & \multirow[t]{2}{*}{ Df } & \multirow[t]{2}{*}{$\begin{array}{l}\text { Sig (2- } \\
\text { tailed) }\end{array}$} & \multirow[t]{2}{*}{$\begin{array}{l}\text { Mean } \\
\text { difference }\end{array}$} & \multirow[t]{2}{*}{$\begin{array}{l}\text { Std. error } \\
\text { Difference }\end{array}$} & \multicolumn{2}{|c|}{$\begin{array}{l}95 \% \text { confidence } \\
\text { interval of the } \\
\text { difference }\end{array}$} \\
\hline & & & & & & & & Lower & Upper \\
\hline $\begin{array}{l}\text { Equal variances assumed } \\
\text { Equal Variances not assumed }\end{array}$ & 6.304 & .012 & $\begin{array}{l}5.541 \\
5.488\end{array}$ & $\begin{array}{l}61 \\
44.212\end{array}$ & $\begin{array}{l}.00 \\
.00\end{array}$ & $\begin{array}{l}3.484 \\
3.484\end{array}$ & $\begin{array}{l}.629 \\
.635\end{array}$ & $\begin{array}{l}4.741 \\
4.763\end{array}$ & $\begin{array}{l}2.227 \\
2.205\end{array}$ \\
\hline
\end{tabular}


The aforementioned stated result of the table was calculated with independent samples T-test. As confirmed from the given result of quasi-experimental study, significance difference was observed between the students in the experimental and control groups. The result of independent samples T-test indicated that the experimental group performed significantly better than the control group $(t=5.54, \mathrm{p}=0.012)$.

\section{CONCLUSION}

The main focus of the study was to confirm the effect critical reflection exerts on students' motivation of learning critical reading skills. First, pre-intervention questionnaire was conducted to students in the experimental and control groups. Having checked the homogeneous nature of participants in both groups, intervention was taken place on the side of students in the experimental group to overview the effect of critical reflection on students' motivation of learning critical reading skills.

To practice critical reflection in reading classes, different techniques were employed: diaries, conversations, interviews, and questionnaires, lesson recordings and journal writing. After intervention, post-intervention questionnaire was administered to students to overview motivation variations of learning critical reading among participants in the experimental and control groups.

When the post-intervention questionnaire results of the participants of both groups compared, students in the experimental group had better motivation than the controlled ones to learn critical reading. From the data analyzed, it can be concluded that practicing critical reflection in reading classes has considerable positive effect in motivating students while learning critical reading skills. Students' post-questionnaire results, in the experimental group after treatment was provided regarding standardized motivation questionnaire questions, can prove that critical reflection can affect positively on the students' motivation of learning critical reading skills in reading classes.

\section{REFERENCES}

[1] AbdKadir, N., Nsubki, R., Haneem, F., \& Ismail, J. (2014). The Importance of Teaching Critical Reading Skills in a Malaysian Reading Classroom. WEI International Academic Conference Proceeding, Bali, Indonesia.

[2] Al-Kalbani, U. (2007). Encouraging Teachers to be Reflective: Advantage, Obstacles, and Limitations. School of Linguistics and Applied Language Studies. Carleton University. Ontario, Canada: Unpublished Thesis.

[3] Al-Oqaili, M. (2007). Jordanian Undergraduate EFL Students' Critical eading Skills. Unpublished Master's Thesis. Yarmouk University, Irbid, Jordan.

[4] Bartlett, L. (1990). Teacher development through reflective teaching. Second Language Teacher Education. New York: Cambridge University Press: 202-214

[5] Benson, M. J. (1991). Attitudes and motivation towards English: a survey of Japanese freshmen. RELC Journal, 22(1), 34-48.

[6] Bolstad, R., \& Gilbert, J. (2012). Supporting future-oriented learning and teaching: A New Zealand perspective. Wellington: Ministry of Education.

[7] Brookfield, S. D. (1995). Becoming a Critically Reflective Teacher. San Francisco: Jossey-Bass.

[8] Brookfield, S. (1988). Developing Critically Reflective Practitioners: A Rationale for Training Educators of Adults. Training Educators of Adults: The Theory and Practice of Graduate Adult Education. Brookfield (Ed). New York: Routledge.

[9] Brown, H. D. (2001). Teaching by principles, 2nd Ed. New York: Longman.

[10] Deci, E. L., Koestner, R., \& Ryan, R. M. (1999). A meta-analytic review of experiments examining the effects of extrinsic rewards on intrinsic motivation. Psychological Bulletin, 125(6), 627-668.

[11] Dewey, J. (1933). How we think: A restatement of the relation of reflective thinking to the educative process. Boston: D.C. Heath \& Co.

[12] Dewey, J. (1916). Democracy and Education: An Introduction to the Philosophy of Education. London: Macmillan.

[13] Dewey, J. (1910). How we think. Lexington, MA: D C Heath. doi:10.1037/10903-001.

[14] Dörnyei, Z. (2001). New themes and approaches in L2 motivation research. Annual Review of Applied Linguistics, 21(1), 43-59.

[15] Driscoll, J. (2007). Practising Clinical Supervision: A Reflective Approach for Healthcare Professionals. (2nd edition). Edinburgh: Bailliere Tindall Elsevier.

[16] El-Maleh, A. (2006). The Effectiveness of a Proposed Literature Circles Program on Developing Critical Reading Secondary School Students Through Teaching Short story. Mansoura University Journal, 1(62), 1-20.

[17] Fook, J., \& Gardner, F. (2007). Practising critical reflection: a resource handbook. Maidenhead: Open University Press.

[18] Freire, P. (1998). Pedagogy of freedom: Ethics, democracy and civic courage. Lanham, MD: Rowman and Littlefield.

[19] Freire, P. (1974). Education for critical consciousness. London: Sheed and Ward.

[20] Freire, P. (1972). Pedagogy of the oppressed. Harmondsworth: Penguin.

[21] Gardner, R. (2006). The socio-educational model of second language acquisition: a research paradigm. EUROSLA Yearbook, 6, 237-260.

[22] Gardner, R. C. (1985). Social psychology and second language learning: The roles of attitudes and motivation. London: Edward Arnold.

[23] Ghaye, T. (2001). Empowerment through Reflection: Competence for the new millennium or a case of the emperor's new clothes? In C. Velde (Ed.), International perspectives on competence in the workplace. Dordrecht, The Netherlands: Kluwer Academic Publishers.

[24] Gibbs, G. (1988). Learning by Doing: A Guide to Teaching and Learning Methods. Oxford: Further Education Unit, Oxford Brookes University. 
[25] Glasersfeld, E. (1989). Cognition, construction of knowledge, and teaching. Synthese, 80(1), 121-140.

[26] Granville, S. (2003). Contests over meaning in a South African classroom: introducing critical language awareness in a climate of social change and cultural diversity. Language and Education, 17(1), 1-20

[27] Icmez, S. (2005). The impact of a critical reading course in the Turkish high school context. Unpublished PhD thesis, University of Warwick, Centre for English Language Teacher Education: UK.

[28] Johns, C. (2009). Becoming a Reflective Practitioner. London: John Wiley \& Sons.

[29] Kolb, D. A. (1984). Experiential learning: Experience as the source of learning and development. New Jersey: Prentice-Hall.

[30] Kumaravadivelu, B. (2001). Toward post method pedagogy. TESOL Quarterly, 35 (4), 535-545.

[31] Lantolf, J.P. (Ed.). (2000). Sociocultural theory and second language learning. Oxford, UK: Oxford University Press.

[32] Larrivee, B. (2000). Transforming Teaching Practice: becoming the critically reflective teacher: Reflective Practice, 1 (3), $293-$ 307.

[33] Leedy, P. and Ormrod, J. (2001). Practical research: Planning and design (7th ed.). Upper Saddle River, NJ: Merrill Prentice Hall. Thousand Oaks: SAGE Publications. Saunders.

[34] Leijen, A., Valtna, K., Leijen, D. A. J. \& Pedaste, M. (2011). How to determine the quality of students' reflections? Studies in Higher Education, 1-15. doi:10.1080/03075079.2010.504814.

[35] Linnenbrink, E. A., \& Pintrich, P. R. (2002). Motivation as an enabler for academic success. The School Psychology Review, 31, 313-327.[Web of Science ®], [Google Scholar].

[36] Locke, E. A., \& Latham, G. P. (1990). Work motivation and satisfaction - Light at the end of the tunnel. Psychological Science, $1,240-246$.

[37] Lowenthal, P., \& Muth, R. (2008). Constructivism. In E.F. Provenzo, Jr. (Ed), Encyclopedia of the social and cultural foundations of education. Thousand Oaks, CA: Sage.

[38] Martin, A. J. (2008). Enhancing student motivation and engagement: The effects of a multidimensional intervention. Contemporary Educational Psychology, 33, 239-269. doi:10.1016/j.ced.

[39] Mezirow, J .(2006). An overview of transformative learning. Lifelong learning: Concepts and contexts (pp 20-30): New York: Routledge.

[40] Mezirow, J. (2000). Learning as transformation: Critical perspectives on a theory in progress. San Francisco: Jossey-Bass

[41] Mezirow, J. (1990). How critical reflection triggers transformative learning. Fostering Critical Reflection in Adulthood (pp 110): Jossey-Bass Publishers, San Francisco.

[42] Midraj, S., Midraj, J., O'Neill, G. \& Sellami, A. (2008). The affective factors and English language attainment of Arab EFL learners. International Journal of Applied Educational Studies. (Online) Retrieved 26 October, 2008 from http://findarticles. com/p /articles /mi_6943/is_/ai_n28532842.

[43] Murphy, P. (2009). Applying a socio-cultural approach to assessment theory and practice: issues for summative and formative assessment: paper presented at the assessment issues and practice, Queensland University of Technology.

[44] Osterman, L. F. \& Kottkamp, R.B. (1993). Reflective Practice for Educators: Improving Schooling through Professional Development. London, Sage Publications Ltd.

[45] Pinder, C. C. (1998). Work motivation in organizational behavior. Upper Saddle River, NJ: Prentice Hall.

[46] Pintrich, P. R. \& Schunk, D. H. (2002). Motivation in education: Theory, research, and application. (2nd, ed.). New Jersey: Merrill Prentice Hall.

[47] Redmond, B. (2004). Reflection in action: Developing reflective practice in health and social services. Aldershot: Ashgate.

[48] Reflective Practice CD ROM. (2007). A "Critical” Reflective Framework: Information Sheet. Reid, B. (1993). "But we're doing it already". Exploring a response to the concept of reflective practice in order to improve its facilitation Nurse education today, pp. 305-309.

[49] Richards, J.C. (1990). The teacher as self-observer. In J.C. Richards (ed.), The language teaching matrix. New York: Cambridge University Press: 118-143.

[50] Rolfe, G., Freshwater, D. \& Jasper, M. (2001). Critical Reflection in Nursing and the Helping Professions: A User's Guide. Basingstoke: Palgrave Macmillan.

[51] Ryan, K. \& Cooper, J. M. (2006). Those who can, teach. Boston: Houghton Mifflin.

[52] Ryan, M.R. \& Deci, E.L. (2004). Avoiding Death or Engaging Life as Accounts of Meaning and Culture: Comment on Pyszczynski et al.; (2004). Psychological Bulletin, 130 (3), pp. 473-477

[53] Samuel,S.S. (1999). Reflective thought, critical thinking. ERIC Clearing house on Reading English and Communication Bloomington IN. (ERIC Document Reproduction Service No. ED 143).

[54] Schön, D.A. (1987). Educating the reflective practitioner: Toward a new design for teaching and learning in the professions. San Francisco: Jossey-Bass.

[55] Schön, D. A. (1983). The Reflective Practitioner: How Professionals Think in Acton. London: Temple Smith.

[56] Surbeck, E., Park Han, E. \& Moyer, J. (1991). Assessing Reflective Responses in Journals. Educational Leadership. March, 2527.

[57] Thorkildsen, T. A. (2002). Motivation and the struggle to learn: Responding to fractured lie. Boston: Allyn \& Bacon.

[58] Vallerand, R. J., Pelletier, L. G., Blais, M. R., Brière, N. M., Senécal, C., \& Vallières, E. F. (1992). The Academic Motivation Scale: A measure of intrinsic, extrinsic, and amotivation in education. Educational and Psychological Measurement, 52, 10031019.

[59] Vygotsky, L. S. (1978). Mind in Society: The Development of Higher Psychological Processes, Cambridge, MA: Harvard University Press.

[60] Walker, R., Cooke, M., Henderson, M. \& Creedy, D.K. (2013). Using a critical reflection process to create an effective learning community in the workplace, Nurse Education Today, Vol. 33 No. 5, pp, 504-511.

[61] Wheeler, L. K. (2007). Critical Reading of an Essay's Argument. Retrieved April 20, 2013 fromhttp://web.cn.edu/ kwheeler/reading_basic.html.

[62] White, S., Fook J. \& Gardner, F. (2006). Critical reflection in health and social care. Maidenhead: Open University Press. 
[63] Zalipour, A. (2015). Reflective Practice. Teaching Development unit. The University of Waikato: Waikato.

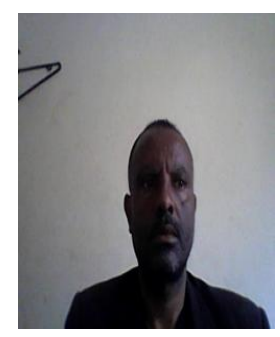

Yeshambel Tadele Alem. He is from Ethiopia. The author works at Debre Markos University. He was born in 8/8/1978. The author started teaching English in primary school after holding his diploma at Bahir Dar University in teaching English in 2002. And, he got Bachelor Dgree in the same university in 2008 in the Department of English Language and Literature. Then, the author continued education to get his second degree in TEFL program in the aforementioned university and he graduated the program in 2011. Now, the author is a PhD student in Bahir Dar University in TEFL program. 